\title{
Chemical and Mineral Composition, Kinetics of Degradation and in vitro Gas Production of Native Cactus*
}

\author{
André Luiz Rodrigues Magalhães \\ Academic Unit of Garanhuns, Federal Rural University of Pernambuco, Garanhuns-PE, \\ Brazil \\ E-mail: andre30036@gmail.com
}

\begin{abstract}
Ana Lúcia Teodoro
Federal Institute of Education, Science and Technology of Piauí, Corrente-PI, Brazil E-mail: analuciazoo@yahoo.com.br
\end{abstract}

Glayciane Costa Gois (Corresponding author)

Postgraduate Program in Veterinary Sciences in the Semi-arid, Federal University of San Francisco Valley, Petrolina-PE, Brazil

E-mail: glayciane_gois@yahoo.com.br

\section{Fleming Sena Campos}

Postgraduate Program in Animal Science and Pastures, Academic Unit of Garanhuns, Federal Rural University of Pernambuco, Garanhuns-PE, Brazil

E-mail: flemingcte@yahoo.com.br

Julyana de Sena Rodrigues Souza

Postgraduate Program in Animal Science, Federal Rural University of Pernambuco, Recife-PE, Brazil

E-mail: julyana_sena@hotmail.com

*Part of the fifth author's dissertation, funded by Banco do Nordeste do Brasil - BNB and Coordenação de Aperfeiçoamento de Pessoal de Nível Superior - CAPES 


\title{
Macrothink
}

Journal of Agricultural Studies

ISSN 2166-0379

2019, Vol. 7, No. 4

Alberício Pereira de Andrade

Academic Unit of Garanhuns, Federal Rural University of Pernambuco, Garanhuns-PE, Brazil

E-mail: albericio3@gmail.com

Isislayne Estevão de Lima

Animal Science Student, Rural Federal University of Pernambuco - Garanhuns Academic Unit, Garanhuns-PE, Brazil

E-mail: isisestev@gmail.com

Leandro Pereira de Oliveira

Integrated PhD Program in Animal Science, Federal University of Paraíba, Areia-PB, Brazil

E-mail: leandro.po@gmail.com

Daniel Bezerra do Nascimento

Postgraduate Program in Animal Science and Pastures, Academic Unit of Garanhuns, Federal Rural University of Pernambuco, Garanhuns-PE, Brazil

E-mail: daniel.nasscimento@ hotmail.com

Received:, 2019 Accepted:, 2019 Published:, 2019

doi:10.5296/jas.v7i4. URL: https://doi.org/10.5296/jas.v7i4.

\begin{abstract}
This study aimed to evaluate the chemical and minerals composition, fractions of carbohydrate and nitrogen compounds, kinetics of degradation and in vitro gas production of native cactus species of the brazilian Semiarid. The experiment was conducted in a completely randomized design, with five native cactus species and 4 replications per species were randomly selected. The native cactus species evaluated were: Cereus jamacaru DC., Melocactus bahiensis Br. Et Rose Werderm, Opuntia inamoene K. Schum, Pilosocereus gounellei (A. Weber ex K. Schum) Bly ex Rowl and Pilosocereus pachycladus Ritter, all in natura. The native cactus species showed differences for chemical and mineral compositions $(\mathrm{P}<0.05)$. The nitrogenous components, $C$. jamacaru cactaceae presented higher contents of fractions A $(228.1 \mathrm{~g} / \mathrm{kg} \mathrm{CP})$ and B3 $(241.7 \mathrm{~g} / \mathrm{kg} \mathrm{CP})$ and smaller fraction C (174.0 g/kg CP). For carbohydrate fraction $C$.
\end{abstract}


jamacaru presented lower fractions A + B1 (412.2 g/kg TC) and C (38.2 g/kg TC) and high fraction B2 (549.7 g/kg TC) and low fraction C. The cactus C. jamacaru and M. bahiensis presented a high PD (856.6 and $837.9 \mathrm{~g} / \mathrm{kg} \mathrm{DM}$, respectively). The parameters a and $\mathrm{b}$ and the effective degradability present diferences $(\mathrm{P}<0.05)$ in function of $2 \%$ and $5 \%$ passage rate. The in vitro true digestibility of dry matter was above $700 \mathrm{~g} / \mathrm{kg}$ of DM for all species. Cactus have high levels of potentially digestible fractions of total carbohydrates, indicating their importance as food for ruminants in created in the semiarid, where Caatinga vegetation is a basal resource.

Keywords: Cactaceae, In vitro fermentation, semiarid

\section{Introduction}

The semiarid region of Brazil is characterized by a temporal and spatial variation of rainwater pulses concentrated in only a few months of the year in most cases. Considering the local edaphoclimatic conditions, it can be stated that forage production in the semiarid is challenging (Pinheiro et al., 2017; Chaves et al., 2019). In this context, the search for food alternatives that enable animal production in the Brazilian semiarid is essential, making use of adapted or native forage plants can be considered as the main forage support for the food shortage period. In addition, the cactus pear, as well as the other native semiarid cacti, such as Opuntia inamoene K. Schum (common name: Quipá), Cereus jamacaru DC. (common name: Mandacaru), Pilosocereus pachycladus Ritter (common name: Facheiro) and Pilosocereus gounellei (A. Weber ex K. Schum). Bly ex Rowl (common name: Xique-xique), have great forage potential because they are adapted to the region's edaphoclimatic conditions, enabling satisfactory dry matter yields per unit area, source of energy and fiber (Lucena et al., 2013; Monteiro et al., 2015; Carvalho et al., 2018).

Several studies have been conducted on the use of native and exotic plants adapted the Semiarid, using them as a forage resource and supplying the scarcity of information about the nutritional values and the feeding attributes of ruminants. Silva et al., (2010), studying the use of native cactus (Cereus jamacaru and Pilosocereus gounellei) associated with different sources of fiber (sabiá hay, silk flower and mesquite pods), observed that all diets evaluated met the nutritional requirements of animals and also promoted a gain of $89 \mathrm{~g} /$ day per animal. Such combinations are considered by the authors as satisfactory for the Semiarid region. Furtado et al., (2016), studying Pilosocereus gounellei comprising up to $36 \%$ of the diet of lactating cows, observed that animals that ate a great proportion of this cactus increased the intake of water from food and reduced the intake of drinking water. In addition, the animals kept the milk production efficiency. The authors then stated that this cactus can be used in the diet of lactating cows without losses on the herd productivity.

The determination of the minerals, fractions of carbohydrates and proteins and the kinetic parameters of ruminal degradation is of utmost importance for nutritionists (Kalegowda et al., 2015; Alves et al., 2017). This information can be used in modern feed formulations for ruminants to maximize the synchronization of degradation of carbohydrates and nitrogen compounds, minimizing energy and nitrogen losses due to ruminal fermentation and promoting a greater efficiency of microbial synthesis (Boufennara et al., 2016; Santos et al., 2019). 


\section{Ml Macrothink}

Journal of Agricultural Studies

ISSN 2166-0379

2019, Vol. 7, No. 4

Therefore, it is necessary to further study the fractions of chemical components of such foods and the kinetics of degradation of the compounds present in such plants to optimize their use for the diet of ruminants.

Thus, the objective of this study is to evaluate the chemical and mineral composition, fractions of carbohydrate and nitrogen compounds, kinetics of degradation and in vitro gas production of native cactus species of the brazilian semiarid.

\section{Materials and Methods}

\subsection{Site Description}

The study was carried out in the Federal Rural University of Pernambuco (UFRPE), academic Unit of Garanhuns, located in Garanhuns, Pernambuco - Brazil. Their study follows the principles of the Declaration of Helsinki.

\subsection{Samples and Experimental Design}

The samples were collected at four distinct points in the Caatinga área, in the Rural Technology Development and Diffusion Station of Sertão Alagoano, located in the city of Piranhas, Alagoas - Brazil. The experiment was conducted in a completely randomized design, with 5 native cactus species (treatments) and 4 replications per species were randomly selected. The native cactus species evaluated were: Cereus jamacaru DC. (Mandacaru), Melocactus bahiensis Br. Et Rose Werderm. (Coroa de Frade), Opuntia inamoene K. Schum (Quipá), Pilosocereus gounellei (A. Weber ex K. Schum) Bly ex Rowl (Xiquexique) and Pilosocereus pachycladus Ritter (Facheiro), all in natura.

\subsection{Preparation of the Samples for Analysis}

The spines of M. bahiensis, $P$. gounellei and P. pachycladus were removed. For the species $C$. jamacaru, the central portion or core of the plant was discarded, because it was a rigid structure. Only the outer part of the plant was used, in which the spines were previously removed.

Samples were pre-dried in a forced ventilation oven at $55^{\circ} \mathrm{C}$ for $72 \mathrm{~h}$ and ground to $1-\mathrm{mm}$ and $2 \mathrm{~mm}$-sized particles (Wiley mill, Marconi, MA - 580, Piracicaba, Brazil) to determine the chemical composition, mineral composition, gas production, degradability and in vitro digestibility assays.

\subsection{Chemical Analysis}

All chemical analyses were carried out using the procedures described by the AOAC (2016) for dry matter (DM, method 967.03), organic matter (OM), mineral matter (MM, method 942.05), ether extract (EE, method 920.29) and crude protein (CP, method 981.10). Neutral detergent fiber (NDF) and acid detergent fiber (ADF) were determined according to the methodology proposed by Van Soest et al., (1991). Neutral detergent fiber corrected for ash (a) and protein (p) (using thermo-stable alpha-amylase, without sodium sulfite) (NDFap; Mertens 2002; Licitra et al., 1996) and lignin was determined by treating the acid detergent fiber residue with $72 \%$ sulfuric acid (Silva and Queiroz, 2002). The pectin was quantified 
according to Canteri-Shemin et al., (2005) with changes of Zanella \& Taranto (2015). The fractions of cellulose (CEL) and hemicellulose (HEM) were estimated by the equations: CEL $=\mathrm{ADF}-\mathrm{LIG}$ and HEM $=\mathrm{NDF}-\mathrm{ADF}$. The total digestible nutrients (TDN) and digestible energy (DE) were estimated using the NRC (2001).

\subsection{Mineral Composition}

The concentrations of phosphorus $(\mathrm{P})$, potassium $(\mathrm{K})$, calcium $(\mathrm{Ca})$, magnesium $(\mathrm{Mg})$, sulfur $(\mathrm{S}),(\mathrm{B})$ copper $(\mathrm{Cu})$, iron $(\mathrm{Fe})$, manganese $(\mathrm{Mn})$, and zinc $(\mathrm{Zn})$ were determined according to the methodologies described by Nogueira \& Souza (2005). Sodium and potassium levels were determined by flame photometry, whereas the concentrations of $\mathrm{Ca}$ and $\mathrm{Mg}$ were analyzed by titration, by determining the $\mathrm{Ca}$ contents, and subsequently the $\mathrm{Ca}+\mathrm{Mg}$ contents, and the $\mathrm{Mg}$ concentration was defined as the difference. Sulfur levels were determined indirectly, first by obtaining the concentrations of sulfates and subsequently, by considering the atomic molecular weight, the concentration of $\mathrm{S}$ were determined. Phosphorus was determined using a molecular spectrophotometer while the determination of $\mathrm{B}, \mathrm{Cu}, \mathrm{Fe}, \mathrm{Mn}$ and $\mathrm{Zn}$, was performed on an atomic absorption spectrophotometer (model Analyst 100, Perkin Elmer®).

\subsection{Fractionation of Carbohydrate and Protein}

Total carbohydrates (TC) were calculated according to Sniffen et al., (1992), where: TC (\% $\mathrm{DM})=100-(\mathrm{CP}+\mathrm{EE}+\mathrm{MM})$. Non-fibrous carbohydrate (NFC), corresponding to the fractions $\mathrm{A}+\mathrm{B} 1$, was measured by the equation $\mathrm{NFC}=100-(\mathrm{CP}+\mathrm{NDFap}+\mathrm{EE}+\mathrm{MM})$. The fraction $\mathrm{C}$ was obtained by the indigestible NDF after 288 hours in situ incubation, as described by Valente et al., (2011). The fraction B2 (digestible fiber) was obtained by the difference between NDFap total carbohydrate and C fraction (indigestible fiber).

Non-protein nitrogen (fraction A), neutral detergent insoluble nitrogen (NDIN) and acid detergent insoluble nitrogen (ADIN) were estimated according to the methodology described by Licitra et al., (1996). The protein fractionation was calculated by the CNCPS system (Sniffen et al., 1992). The protein was analyzed and calculated for the five fractions, A, B1, B2, B3 and C. The fraction A, made up by NPN compounds, was determined by the difference between total $\mathrm{N}$ and trichloroacetic acid (TCA) insoluble nitrogen with the formula: $\mathrm{A}(\% \mathrm{Nt})=\mathrm{Nt}-\mathrm{N} 1 / \mathrm{Nt} \times 100$, where $\mathrm{Nt}=$ total nitrogen of the sample, and $\mathrm{N} 1=$ content of trichloroacetic acid insoluble nitrogen.

The fraction B1 refers to soluble protein, rapidly degraded in the rumen, obtained by the difference between the borate phosphate buffer (TBF) insoluble nitrogen minus the NPN, by the formula: $\mathrm{B} 1(\% \mathrm{Nt})=\mathrm{N} 1-\mathrm{N} 2 / \mathrm{Nt} \times 100$, where: $\mathrm{N} 2=$ borate phosphate buffer insoluble nitrogen. The fractions $\mathrm{B} 2$ and B3 consist of insoluble protein with intermediate-slow degradation rate in rumen, determined by the difference between the borate phosphate buffer insoluble nitrogen and NDIN, the NDIN minus the ADIN, respectively. The value of B2 is achieved with B2 $(\% \mathrm{Nt})=\mathrm{N} 2-\mathrm{NIDN} / \mathrm{Nt} \times 100$ and the fraction B3, with B3 $(\% \mathrm{Nt})=\mathrm{NDIN}$ - ADIN/Nt x 100. The fraction $\mathrm{C}$ is formed by insoluble protein indigestible in the rumen and intestine, and was determined by the content of residual nitrogen of the sample after treated with acid detergent and expressed in percentage of $\mathrm{Nt}$ of the sample. 


\section{7 "in vitro" Ruminal Degradation Kinetics by Gas Production}

The in vitro dry matter degradability was performed according to the first stage of the Tilley e Terry (1963) method, using a nutrient medium of Marten \& Barnes (1979) through in vitro incubations of $600 \mathrm{mg}$ of dry air sample with $60 \mathrm{~mL}$ of buffer solution (combination of solutions $\mathrm{A}+\mathrm{B}$ with $\mathrm{pH} 6.8$ ) and $15 \mathrm{~mL}$ of inoculum collected from ruminal inoculum collected from two rumen fistulated sheeps, filtered in four layers of gauze, constantly injecting carbon dioxide to maintain the anaerobic environment. Samples were incubated at 0, $3,6,9,12,18,24,36$ and 48 hours, whereas at time zero the samples underwent only a washing under distilled water at $39^{\circ} \mathrm{C}$. In the other times, the samples were incubated in an oven with a constant temperature of $39^{\circ} \mathrm{C}$.

In vitro degradation parameters $(a, b$ and $c$ ) and potential dry matter degradability were estimated using the model proposed by Orskov \& McDonald (1979): $P D=a+b\left(1-e^{-c t}\right)$ using the PROC NLIN procedure of the SAS software, where $P D$ is the actual percentage of nutrient degraded after $\mathrm{t}$ hours of incubation, $a$ is readily soluble fraction, $\mathrm{b}$ is the fraction that can be degraded if there is time, $c$ is $b$ fraction degradation rate or speed, and $t$ is incubation time. To estimate the effective degradability (ED), the following equation was used: $\mathrm{ED}=a+$ $\left(b^{*} c\right) /(c+\mathrm{k})$, where $\mathrm{k}$ is food passage rate. Rumen particle passage rates are estimated at 0.02 , 0.05 and $0.08 \mathrm{~h}^{-1}$ as suggested by AFRC (1993).

The analysis of in vitro dry matter digestibility (IVDMD) was conducted according to Tilley \& Terry (1963), with the modifications proposed by Holden (1999), through in vitro incubations of $1 \mathrm{~g}$ of dry sample in air, with $80 \mathrm{~mL}$ of buffer solution and $20 \mathrm{~mL}$ of ruminal fluid, filtered in four layers of gauze, constantly injecting carbon dioxide to maintain the anaerobic environment. After 48 hours of incubation, $6 \mathrm{~mL}$ of $20 \%$ hydrochloric acid $(\mathrm{HCl})$ and $2 \mathrm{~mL}$ of pepsin (1: 1000) were added into each vial and, after the 24 hours incubation period, the filtration procedures were performed vacuum, drying and weighing of the waste, in order to calculate the IVDMD.

For in vitro gas production, $1.0 \mathrm{~g}$ of sample was added to glass bottles (160 mL), to which 90 $\mathrm{mL}$ of nutrient medium were added, according to Theodorou et al., (1994). Subsequently, 10 $\mathrm{mL}$ of rumen fluid (from the rumen of three goats) were added to each vial, which was kept under $\mathrm{CO}_{2}$ aspersion. Then, they were sealed with rubber corks and aluminum seals. The pressure caused by fermentation was measured using a pressure transducer (Datalogger Universal Logger AG100 - Agricer). The readings were made with a higher rate during the initial period and with a lower rate towards the end of the study period $(2,4,6,8,10,12,15$, $18,21,24,30,36,42$ and 48 hours of incubation). The pressure in PSI (pressure per square inch) were converted into volume of gas $(\mathrm{V})$ by the equation $\mathrm{V}=5.1612 * \mathrm{psi}-0.3017, \mathrm{R}^{2}=$ 0.9873, generated in the Production Laboratory (LPG) of the Academic Unit of Garanhuns, UFRPE, based on 937 observations (-8 $90^{\prime} 77^{\prime \prime} \mathrm{S},-36^{\circ} 49^{\prime} 49^{\prime \prime} \mathrm{W}$, altitude 844 meters). 1 psi = $4.859 \mathrm{~mL}$ of gas. From each pressure reading, the total produced by the bottles without substrate (white), for each sample, was subtracted. 


\subsection{Statistical Analysis}

The data obtained from chemical analyses, fractionation of carbohydrates, nitrogenous compounds and IVDMD were submitted to analysis of variance using the PROC GLM procedure. Cumulative gas production data were adjusted by the two-compartment model suggested by Schofield et al.,, (1994) using the procedure NLMIXED of SAS (2011).

$$
\mathrm{V}(\mathrm{t})=\left(\mathrm{V} f 1 / 1+\mathrm{e}^{[2-4 k d 1(\mathrm{~T}-\mathrm{L})]}\right)+\left(\mathrm{V} f 2 / 1+\mathrm{e}^{[2-4 k d 2(\mathrm{~T}-\mathrm{L})]}\right)
$$

where, $\mathrm{V}(\mathrm{t})$ is the maximum total volume of produced gas; Vf1 $(\mathrm{mL})$ is the maximum volume of gas for the rapidly digested carbohydrate fraction (NFC); VF2 (mL) is the maximum volume of gas for the slowly digestion fraction (FC); $k d l\left(\mathrm{~h}^{-1}\right)$ is the rate of degradation of the rapidly digested fraction (NFC); $k d 2\left(\mathrm{~h}^{-1}\right)$ is the rate of degradation of the slowly digested fraction; $L$ is the duration of initial digestion events (lag phase) common to the two phases; and $\mathrm{T}(\mathrm{h})$ is fermentation time.

The means were compared by Tukey test at 5\% significance level using the statistical software Statistical Analysis System $\left(\mathrm{SAS}^{\circledR}\right)$.

\section{Results}

The native cactus species evaluated showed differences for mineral matter $(\mathrm{P}<0.0001)$, organic matter $(\mathrm{P}<0.0001)$, ether extract $(\mathrm{P}<0.0001)$, crude protein $(\mathrm{P}<0.0001)$, neutral detergent insoluble protein $(\mathrm{P}=0.008)$, acid detergent insoluble protein $(\mathrm{P}<0.0001)$, neutral detergent fiber $(\mathrm{P}<0.0001)$, acid detergent fiber $(\mathrm{P}<0.0001)$, hemicellulose $(\mathrm{P}<0.0001)$, acid detergent lignin $(\mathrm{P}<0.0001)$, cellulose $(\mathrm{P}<0.0001)$, non-fiber carbohydrates $(\mathrm{P}<0.0001)$, pectin $(\mathrm{P}=$ $0.014)$, total digestible nutrients $(\mathrm{P}<0.0001)$ and digestible energy $(\mathrm{P}<0.0001)$ (Table 1$)$.

Table 1. Chemical composition of native cactus of the Brazilian Semiarid

\begin{tabular}{|c|c|c|c|c|c|c|c|}
\hline \multirow[b]{2}{*}{ Variables } & \multicolumn{5}{|c|}{ Native cactus species } & \multirow[b]{2}{*}{ SEM } & \multirow[b]{2}{*}{$P$ value } \\
\hline & $\begin{array}{c}\text { Cereus } \\
\text { jamacaru }\end{array}$ & $\begin{array}{c}\text { Melocactus } \\
\text { bahiensis }\end{array}$ & $\begin{array}{l}\text { Opuntia } \\
\text { inamoene }\end{array}$ & $\begin{array}{c}\text { Pilosocereus } \\
\text { gounellei }\end{array}$ & $\begin{array}{l}\text { Pilosocereus } \\
\text { pachycladus }\end{array}$ & & \\
\hline $\mathrm{DM}^{1}$ & $154.1 \mathrm{a}$ & $116.2 \mathrm{a}$ & $135.5 \mathrm{a}$ & $113.5 \mathrm{a}$ & $148.4 \mathrm{a}$ & 5.65 & 0.052 \\
\hline $\mathrm{MM}^{2}$ & $141.3 \mathrm{~cd}$ & $183.1 \mathrm{bc}$ & $116.4 d$ & $267.4 \mathrm{a}$ & $233.6 \mathrm{ab}$ & 14.21 & $<0.0001$ \\
\hline $\mathrm{OM}^{2}$ & $858.5 \mathrm{ab}$ & $816.8 b c$ & $883.6 \mathrm{a}$ & $732.5 \mathrm{~d}$ & $766.4 \mathrm{~cd}$ & 14.2 & $<0.0001$ \\
\hline $\mathrm{EE}^{2}$ & $15.4 \mathrm{~b}$ & $17.4 \mathrm{ab}$ & $25.6 \mathrm{a}$ & $5.7 \mathrm{c}$ & $19.9 \mathrm{ab}$ & 1.67 & $<0.0001$ \\
\hline $\mathrm{CP}^{2}$ & $65.9 \mathrm{a}$ & $59.7 \mathrm{a}$ & $29.8 b$ & $26.0 \mathrm{~b}$ & $52.3 \mathrm{a}$ & 4.08 & $<0.0001$ \\
\hline $\mathrm{NDIP}^{3}$ & $415.7 \mathrm{~b}$ & $457.4 \mathrm{ab}$ & $569.9 \mathrm{ab}$ & $599.5 \mathrm{a}$ & $404.9 \mathrm{~b}$ & 24.17 & 0.008 \\
\hline $\mathrm{ADIP}^{3}$ & $174.0 \mathrm{c}$ & $269.7 \mathrm{bc}$ & $498.8 \mathrm{ab}$ & $476.3 \mathrm{a}$ & $361.4 b$ & 29.6 & $<0.0001$ \\
\hline $\mathrm{NDF}^{2}$ & $457.1 \mathrm{a}$ & $292.0 \mathrm{~d}$ & $402.2 \mathrm{~b}$ & $355.1 \mathrm{bc}$ & $347.7 \mathrm{c}$ & 13.6 & $<0.0001$ \\
\hline $\mathrm{ADF}^{2}$ & $258.5 \mathrm{ab}$ & $260.0 \mathrm{a}$ & $170.7 \mathrm{c}$ & $236.1 \mathrm{~b}$ & $167.6 \mathrm{c}$ & 9.69 & $<0.0001$ \\
\hline HEM & $198.7 \mathrm{a}$ & $32.0 \mathrm{c}$ & $231.6 \mathrm{a}$ & $119.0 \mathrm{~b}$ & $180.0 \mathrm{a}$ & 16.93 & $<0.0001$ \\
\hline $\mathrm{ADL}^{2}$ & $5.6 \mathrm{c}$ & $18.5 b$ & $10.9 \mathrm{bc}$ & $36.0 \mathrm{a}$ & $34.7 \mathrm{a}$ & 2.99 & $<0.0001$ \\
\hline $\mathrm{CEL}^{2}$ & $252.8 \mathrm{a}$ & $241.5 \mathrm{a}$ & $161.3 \mathrm{c}$ & $200.1 b$ & $132.8 \mathrm{~d}$ & 10.65 & $<0.0001$ \\
\hline $\mathrm{NFC}^{2}$ & $320.3 b$ & $447.8 \mathrm{a}$ & $425.9 a$ & $345.7 b$ & $346.4 \mathrm{~b}$ & 12.7 & $<0.0001$ \\
\hline Pectin $^{2}$ & $45.7 b$ & $75.4 \mathrm{ab}$ & $99.9 \mathrm{a}$ & $76.5 \mathrm{ab}$ & $38.8 \mathrm{~b}$ & 6.95 & 0.014 \\
\hline $\mathrm{TDN}^{2}$ & $658.9 \mathrm{a}$ & $637.3 \mathrm{a}$ & $698.7 \mathrm{a}$ & $498.8 \mathrm{~b}$ & $542.3 b$ & 18.3 & $<0.0001$ \\
\hline $\mathrm{DE}^{4}$ & $2.8 \mathrm{a}$ & $2.7 \mathrm{a}$ & $3.0 \mathrm{a}$ & $2.1 b$ & $2.3 b$ & 0.08 & $<0.0001$ \\
\hline
\end{tabular}

Means followed by the same letter in columns do not differ $(\mathrm{P}>0.05)$ by Tukey test, $\mathrm{DM}=$ dry matter, $\mathrm{MM}=$ mineral matter, $\mathrm{OM}=$ organic matter, $\mathrm{EE}=$ ether extract, $\mathrm{CP}=$ crude protein, $\mathrm{NDIP}=$ neutral detergent insoluble protein, $\mathrm{ADIP}=$ acid detergent insoluble protein, $\mathrm{NDF}=$ 
neutral detergent fiber, $\mathrm{ADF}=$ acid detergent fiber, $\mathrm{HEM}=$ hemicellulose, $\mathrm{ADL}=$ acid detergent lignin, $\mathrm{CEL}=$ cellulose $\mathrm{NFC}=$ non-fiber carbohydrates, $\mathrm{TDN}=$ total digestible nutrients, DE = digestible energy, SEM = standard error mean. ${ }^{1} \mathrm{~g} / \mathrm{kg}$ of natural material; ${ }^{2} \mathrm{~g} / \mathrm{kg}$ of $\mathrm{DM} ;{ }^{3} \mathrm{~g} / \mathrm{kg}$ of $\mathrm{CP} ;{ }^{4} \mathrm{Mcal} / \mathrm{kg}$ of DM

Regarding mineral composition, differences were observed between the studied species for the minerals Phosphorus $(\mathrm{P}<0.0001)$, Calcium $(\mathrm{P}=0.0004)$, Magnesium $(\mathrm{P}<0.0001)$, Boron $(\mathrm{P}$ $<0.0001)$, Iron $(\mathrm{P}=0.01)$, Manganese $(\mathrm{P}<0.0001)$ and Zinc $(\mathrm{P}=0.002)$ (Table 2$)$.

Table 2. Mineral composition of native cactus from the Brazilian Semiarid

\begin{tabular}{|c|c|c|c|c|c|c|c|}
\hline \multirow[b]{2}{*}{ Variables } & \multicolumn{5}{|c|}{ Native cactus species } & \multirow[b]{2}{*}{ SEM } & \multirow[b]{2}{*}{$P$ value } \\
\hline & $\begin{array}{c}\text { Cereus } \\
\text { jamacaru }\end{array}$ & $\begin{array}{c}\text { Melocactus } \\
\text { bahiensis }\end{array}$ & $\begin{array}{c}\text { Opuntia } \\
\text { inamoene }\end{array}$ & $\begin{array}{c}\text { Pilosocereus } \\
\text { gounellei }\end{array}$ & $\begin{array}{l}\text { Pilosocereus } \\
\text { pachycladus }\end{array}$ & & \\
\hline $\mathrm{P}^{1}$ & $1.4 \mathrm{~b}$ & $2.7 \mathrm{a}$ & $0.9 \mathrm{c}$ & $0.7 \mathrm{c}$ & $0.5 \mathrm{c}$ & 0.2 & $<0.0001$ \\
\hline $\mathrm{K}^{1}$ & $9.4 \mathrm{a}$ & $11.0 \mathrm{a}$ & $12.3 \mathrm{a}$ & $8.6 \mathrm{a}$ & $10.9 \mathrm{a}$ & 0.5 & 0.15 \\
\hline $\mathrm{Ca}^{1}$ & $38.2 \mathrm{c}$ & $41.3 \mathrm{bc}$ & $35.3 \mathrm{c}$ & $56.1 \mathrm{ab}$ & $58.5 \mathrm{a}$ & 2.6 & 0.0004 \\
\hline $\mathrm{Mg}^{1}$ & $8.7 b$ & $9.1 b$ & $8.4 \mathrm{~b}$ & $16.2 \mathrm{a}$ & $15.3 \mathrm{a}$ & 0.9 & $<0.0001$ \\
\hline $\mathrm{S}^{1}$ & $0.3 \mathrm{a}$ & $0.3 \mathrm{a}$ & $0.7 \mathrm{a}$ & $0.6 \mathrm{a}$ & $0.3 \mathrm{a}$ & 0.1 & 0.23 \\
\hline $\mathrm{B}^{2}$ & $79.8 \mathrm{a}$ & $80.5 \mathrm{a}$ & $63.1 b$ & $88.7 \mathrm{a}$ & $84.5 \mathrm{a}$ & 2.3 & $<0.0001$ \\
\hline $\mathrm{Cu}^{2}$ & $2.3 \mathrm{a}$ & $3.4 \mathrm{a}$ & $2.0 \mathrm{a}$ & $3.5 \mathrm{a}$ & $2.7 \mathrm{a}$ & 0.2 & 0.14 \\
\hline $\mathrm{Fe}^{2}$ & $28.9 b$ & $122.5 \mathrm{ab}$ & $134.8 \mathrm{a}$ & $47.5 \mathrm{ab}$ & $129.9 \mathrm{ab}$ & 13.9 & 0.01 \\
\hline $\mathrm{Mn}^{2}$ & $261.9 \mathrm{c}$ & $359.8 b c$ & $89.5 c$ & $1880.6 \mathrm{a}$ & 1189.8ab & 173.6 & $<0.0001$ \\
\hline $\mathrm{Zn}^{2}$ & $39.4 \mathrm{ab}$ & $24.0 \mathrm{bc}$ & $17.6 \mathrm{c}$ & $49.0 \mathrm{a}$ & $45.0 \mathrm{ab}$ & 3.4 & 0.002 \\
\hline
\end{tabular}

Means followed by the same letter in columns do not differ $(\mathrm{P}>0.05)$ by Tukey test, $\mathrm{SEM}=$ standard error mean. P - Phosphorus; K - Potassium; Ca - Calcium; Mg - Magnesium; S Sulfur; B - Boron; Cu - Copper; Fe - Iron; Mn - Manganese and Zn - Zinc. ${ }^{1}$ g/kg of Dry Matter; ${ }^{2} \mathrm{mg} / \mathrm{kg}$ of Dry Matter.

In relation to the fractions of nitrogen compounds, there were differences $(\mathrm{P}<0.05)$. The high content of the fraction A corresponds to the non-protein nitrogen (NPN) in the species $C$. jamacaru $(228.1 \mathrm{~g} / \mathrm{kg} \mathrm{CP})$, followed by M. bahiensis $(146.2 \mathrm{~g} / \mathrm{kg} \mathrm{CP})$, O. inamoene (102.3 $\mathrm{g} / \mathrm{kg} \mathrm{CP}$ ) and $P$. pachycladus $(83.2 \mathrm{~g} / \mathrm{kg} \mathrm{CP})$. There was a low content of fraction A in $P$. gounellei $(54.2 \mathrm{~g} / \mathrm{kg} \mathrm{CP})$. For the fractions $\mathrm{B} 1+\mathrm{B} 2$, there were no differences $(\mathrm{P}>0.05)$ (Table 3).

Table 3. Fractions of nitrogen compounds of native cactus from the Brazilian Semiarid

\begin{tabular}{|c|c|c|c|c|c|c|c|}
\hline \multirow[b]{2}{*}{ Variables } & \multicolumn{5}{|c|}{ Native cactus species } & \multirow[b]{2}{*}{ SEM } & \multirow[b]{2}{*}{$P$ value } \\
\hline & $\begin{array}{c}\text { Cereus } \\
\text { jamacaru }\end{array}$ & $\begin{array}{c}\text { Melocactus } \\
\text { bahiensis }\end{array}$ & $\begin{array}{l}\text { Opuntia } \\
\text { inamoene }\end{array}$ & $\begin{array}{c}\text { Pilosocereus } \\
\text { gounellei }\end{array}$ & $\begin{array}{l}\text { Pilosocereus } \\
\text { pachycladus }\end{array}$ & & \\
\hline $\mathrm{CP}^{1}$ & $65.9 \mathrm{a}$ & $59.7 \mathrm{a}$ & $29.8 b$ & $26.0 \mathrm{~b}$ & $52.3 \mathrm{a}$ & 4.1 & $<0.0001$ \\
\hline $\mathrm{A}^{2}$ & $228.1 \mathrm{a}$ & $146.2 \mathrm{ab}$ & $102.3 \mathrm{ab}$ & $54.2 b$ & $83.2 \mathrm{ab}$ & 19.8 & 0.0292 \\
\hline $\mathrm{B} 1+\mathrm{B} 2^{2}$ & $356.1 \mathrm{a}$ & $396.3 \mathrm{a}$ & $327.7 \mathrm{a}$ & $346.2 \mathrm{a}$ & $511.9 \mathrm{a}$ & 26.5 & 0.177 \\
\hline $\mathrm{B}^{2}$ & $241.7 \mathrm{a}$ & $187.7 \mathrm{ab}$ & $71.2 \mathrm{c}$ & $123.3 \mathrm{bc}$ & $43.5 \mathrm{c}$ & 19.3 & $<0.0002$ \\
\hline $\mathrm{C}^{2}$ & $174.0 \mathrm{c}$ & $269.7 \mathrm{bc}$ & $498.8 \mathrm{a}$ & $476.3 \mathrm{a}$ & $361.4 \mathrm{~b}$ & 29.6 & $<0.0001$ \\
\hline
\end{tabular}


Means followed by the same letter in columns do not differ $(\mathrm{P}>0.05)$ by Tukey test, $\mathrm{SEM}=$ standard error mean, $\mathrm{CP}=$ Crude protein, $\mathrm{A}=$ non-protein nitrogen, $\mathrm{B} 1+\mathrm{B} 2=$ high and average rumen nitrogen degradation fraction, $\mathrm{B} 3=$ slow nitrogen degradation fraction, $\mathrm{C}=$ unavailable nitrogen fraction. ${ }^{1} \mathrm{~g} / \mathrm{kg}$ of $\mathrm{DM} ;{ }^{2} \mathrm{~g} / \mathrm{kg}$ of $\mathrm{CP}$.

For the fraction B3, highest values were observed for $C$. jamacaru $(241.7 \mathrm{~g} / \mathrm{kg} \mathrm{CP})$ and the lowest values were observed for P. pachycladus $(45.3 \mathrm{~g} / \mathrm{kg} \mathrm{CP}$ ) (Table 3). The highest values were observed for $O$. inamoene $(498.8 \mathrm{~g} / \mathrm{kg} \mathrm{CP})$ and $P$. gounelli $(476.3 \mathrm{~g} / \mathrm{kg} \mathrm{CP})$, which differed $(\mathrm{P}<0.05)$ from the other cactus. The lowest presence of unavailable protein was observed for C. jamacaru (174.0 g/kg CP) (Table 3).

There were differences $(\mathrm{P}<0.05)$ among the species in the total carbohydrate ratios and their fractions. The highest total carbohydrate compositions were observed for $O$. inamoene (828.2 $\mathrm{g} / \mathrm{kg} \mathrm{DM}$ ) and $C$. jamacaru $(777.4 \mathrm{~g} / \mathrm{kg} \mathrm{DM})$. The lowest total carbohydrate compositions were observed for $P$. pachycladus (694.1 g/kg DM) (Table 4).

Table 4. Fractions of carbohydrate compounds of native cactus of the Brazilian Semiarid

\begin{tabular}{lccccccc}
\hline \multirow{2}{*}{ Variables } & \begin{tabular}{c} 
Cereus \\
\cline { 2 - 6 }
\end{tabular} & $\begin{array}{c}\text { Melocactus } \\
\text { jamacaru }\end{array}$ & $\begin{array}{c}\text { Ophiensis } \\
\text { banamoene }\end{array}$ & $\begin{array}{c}\text { Pilosocereus } \\
\text { gounellei }\end{array}$ & $\begin{array}{c}\text { Pilosocereus } \\
\text { pachycladus }\end{array}$ & SEM & $P$ value \\
\hline $\mathrm{TC}^{1}$ & $777.4 \mathrm{ab}$ & $739.8 \mathrm{bc}$ & $828.2 \mathrm{a}$ & $700.8 \mathrm{c}$ & $694.1 \mathrm{c}$ & 13.0 & $<0.0001$ \\
$\mathrm{~A}+\mathrm{B} 1^{2}$ & $412.2 \mathrm{c}$ & $605.4 \mathrm{a}$ & $514.3 \mathrm{~b}$ & $492.0 \mathrm{~b}$ & $498.9 \mathrm{~b}$ & 15.1 & $<0.0001$ \\
$\mathrm{~B}^{2}$ & $549.7 \mathrm{a}$ & $339.4 \mathrm{bc}$ & $288.0 \mathrm{c}$ & $369.2 \mathrm{~b}$ & $372.5 \mathrm{~b}$ & 21.4 & $<0.0001$ \\
$\mathrm{C}^{2}$ & $38.2 \mathrm{~b}$ & $55.2 \mathrm{~b}$ & $197.7 \mathrm{a}$ & $138.8 \mathrm{a}$ & $128.6 \mathrm{a}$ & 14.9 & $<0.0001$ \\
\hline
\end{tabular}

Means followed by the same letter in columns do not differ $(\mathrm{P}>0.05)$ by Tukey test, $\mathrm{SEM}=$ standard error mean, $\mathrm{TC}=$ Total carbohydrate, $\mathrm{A}+\mathrm{B} 1=$ soluble fraction, $\mathrm{B} 2=$ potentially degradable fiber, $\mathrm{C}=$ indigestible fiber. ${ }^{1} \mathrm{~g} / \mathrm{kg}$ of $\mathrm{DM} ;{ }^{2} \mathrm{~g} / \mathrm{kg}$ of TC.

The highest values of the fraction $\mathrm{A}+\mathrm{B} 1$, which corresponds to carbohydrates with a high degradation rate, were observed for M. bahiensis $(605.4 \mathrm{~g} / \mathrm{kg} \mathrm{TC})$. The highest proportion of the fraction B2 (potentially digestible fiber) was observed for C. jamacaru (549.7 g/kg TC). For the fraction C (unavailable fiber), values of $197.7 \mathrm{~g} / \mathrm{kg}$ TC for $O$. inamoene and $38.2 \mathrm{~g} / \mathrm{kg}$ TC for $C$. jamacaru were observed. These values represent the highest and lowest means observed for the fraction C (Table 4).

Potential degradation was above $60 \%$ for all species and there were differences $(\mathrm{P}<0.05)$ among species (Table 5). The cactus $C$. jamacaru and $M$. bahiensis presented a high PD: 856.6 and $837.9 \mathrm{~g} / \mathrm{kg}$ DM, respectively (Tables 1 and 4).

There were differences $(\mathrm{P}<0.05)$ in the parameters $a$ and $b$ and the effective degradability (ED) in function of a $2 \%$ (slow) and a 5\% (average) passage rate. However, when an ED for a passage rate of $8 \%$ (fast) was estimated, it was observed that there were no differences $(\mathrm{P}>0.05)$ among species.

The in vitro true digestibility of dry matter was above $700 \mathrm{~g} / \mathrm{kg}$ of DM for all species. The highest IVDMD was observed for M. bahiensis $(865.8 \mathrm{~g} / \mathrm{kg}$ of DM). The lowest value was 
found for P. pachycladus (721.1 g/kg DM) (Table 5). Such low IVDMD is due to a high proportion of fiber compounds with a low digestibility in the part $\mathrm{C}$ of the carbohydrates.

Table 5. Kinetics of degradation and in vitro true dry matter digestibility of native cactus of the Brazilian Semiarid

\begin{tabular}{|c|c|c|c|c|c|c|c|}
\hline \multirow[b]{2}{*}{ Variables } & \multicolumn{5}{|c|}{ Native cactus species } & \multirow[b]{2}{*}{ SEM } & \multirow[b]{2}{*}{$\begin{array}{c}P \\
\text { value }\end{array}$} \\
\hline & $\begin{array}{c}\text { Cereus } \\
\text { jamacaru }\end{array}$ & $\begin{array}{c}\text { Melocactus } \\
\text { bahiensis }\end{array}$ & $\begin{array}{l}\text { Opuntia } \\
\text { inamoene }\end{array}$ & $\begin{array}{l}\text { Pilosocereus } \\
\text { gounellei }\end{array}$ & $\begin{array}{l}\text { Pilosocereus } \\
\text { pachycladus }\end{array}$ & & \\
\hline$a^{1}$ & $170.8 \mathrm{c}$ & $255.6 \mathrm{ab}$ & $233.4 b$ & $237.7 \mathrm{ab}$ & $283.2 \mathrm{a}$ & 9.5 & $<0.0001$ \\
\hline$b^{1}$ & $685.9 \mathrm{a}$ & $582.3 \mathrm{~b}$ & $454.5 \mathrm{c}$ & $537.8 \mathrm{bc}$ & $334.7 d$ & 28.5 & $<0.0001$ \\
\hline$c\left(\mathrm{~h}^{-1}\right)$ & $0.04 \mathrm{a}$ & $0.04 \mathrm{a}$ & $0.06 \mathrm{a}$ & $0.04 \mathrm{a}$ & $0.05 \mathrm{a}$ & 0.02 & 0.22 \\
\hline $\operatorname{ED}^{1}\left(0.02 \mathrm{~h}^{-1}\right)$ & 644.9a & $624.1 \mathrm{ab}$ & $566.3 \mathrm{~cd}$ & $592.0 \mathrm{bc}$ & $525.3 d$ & 10.6 & $<0.0001$ \\
\hline $\operatorname{ED}^{1}\left(0.05 \mathrm{~h}^{-1}\right)$ & $495.4 \mathrm{ab}$ & $498.9 \mathrm{a}$ & $471.4 \mathrm{ab}$ & $473.1 \mathrm{ab}$ & $454.4 \mathrm{~b}$ & 5.5 & 0.04 \\
\hline $\operatorname{ED}^{1}\left(0.08 \mathrm{~h}^{-1}\right)$ & $417.6 \mathrm{a}$ & $438.9 a$ & $419.4 \mathrm{a}$ & $414.1 \mathrm{a}$ & $415.6 \mathrm{a}$ & 4.1 & 0.35 \\
\hline $\mathrm{Pd}^{1}$ & $856.6 \mathrm{a}$ & 837.9a & $687.8 \mathrm{bc}$ & $775.4 \mathrm{ab}$ & $618.0 \mathrm{c}$ & 23.2 & $<0.0001$ \\
\hline IVDMD $^{1}$ & $796.6 \mathrm{~b}$ & $865.8 \mathrm{a}$ & $733.4 \mathrm{c}$ & $792.1 b$ & $721.1 \mathrm{c}$ & 12.03 & $<0.0001$ \\
\hline
\end{tabular}

Means followed by the same letter in columns do not differ $(\mathrm{P}>0.05)$ by Tukey test, SEM = standard error mean; $a, b$ and $c$ refer to parameters of Orskov \& McDonald (1979); ED = effective degradability for a passage rate of $0.02,0.05$ and $0.08 \mathrm{~h}^{-1} ; \mathrm{Pd}=$ potential degradability represented by the sum of $a$ and $b$; IVDMD $=$ in vitro true dry matter digestibility. ${ }^{1} \mathrm{~g} / \mathrm{kg}$ of $\mathrm{DM}$.

The production of total gases in vitro $(\mathrm{Vt1})$ and the production adjusted by the bicompartmental model (Vt2) presented differences between species $(\mathrm{P}<0.05)$. TC fermentation resulted in a higher Vt1 for $C$. jamacaru $(267.2 \mathrm{~mL} / \mathrm{g}$ incubated DM) and for $O$. inamoene $(266.2 \mathrm{~mL} / \mathrm{g}$ DM). They did not differ from M. bahiensis $(258.0 \mathrm{~mL} / \mathrm{g} \mathrm{DM})$ (Table 6). The lowest Vt1 produced by TC fermentation of $P$. pachycladus $(192.4 \mathrm{~mL} / \mathrm{g} \mathrm{DM})$ was due to the low proportion of total carbohydrates present in its composition, and also due to a low $\mathrm{Pd}$.

There was a difference $(\mathrm{P}<0.05)$ in the gas production from the fermentation of non-fiber carbohydrates (Vf1). The C. jamacaru produces most gases, which differed from all other species. On the other hand, the production of gases by the degradation of fiber carbohydrates (Vf2) was low for C. jamacaru, not differing from O. inamoene and P. pachycladus (Table 6).

Table 6. Kinetics of in vitro gas production of native cactus of the Brazilian Semiarid

\begin{tabular}{|c|c|c|c|c|c|c|c|}
\hline \multirow[b]{2}{*}{ Variables } & \multicolumn{5}{|c|}{ Native cactus species } & \multirow[b]{2}{*}{ SEM } & \multirow[b]{2}{*}{$\begin{array}{c}P \\
\text { value }\end{array}$} \\
\hline & $\begin{array}{c}\text { Cereus } \\
\text { jamacaru }\end{array}$ & $\begin{array}{c}\text { Melocactus } \\
\text { bahiensis }\end{array}$ & $\begin{array}{c}\text { Opuntia } \\
\text { inamoene }\end{array}$ & $\begin{array}{l}\text { Pilosocereus } \\
\text { gounellei }\end{array}$ & $\begin{array}{l}\text { Pilosocereus } \\
\text { pachycladus }\end{array}$ & & \\
\hline $\mathrm{V}_{\mathrm{t} 1}$ & $277.4 \mathrm{a}$ & $258.0 \mathrm{ab}$ & $266.2 \mathrm{a}$ & $222.2 \mathrm{bc}$ & $192.4 \mathrm{c}$ & 8.2 & $<0.0001$ \\
\hline$V_{t 2}$ & $300.4 a$ & $265.4 \mathrm{ab}$ & $265.3 \mathrm{ab}$ & $227.4 \mathrm{bc}$ & $196.5 \mathrm{c}$ & 9.2 & $<0.0001$ \\
\hline$V_{f 1}$ & $239.9 a$ & $162.1 b c$ & $174.2 b$ & $126.3 \mathrm{~cd}$ & $119.0 \mathrm{~d}$ & 10.5 & $<0.0001$ \\
\hline$k_{l}$ & $0.21 \mathrm{a}$ & $0.09 \mathrm{a}$ & $0.11 \mathrm{a}$ & $0.10 \mathrm{a}$ & $0.10 \mathrm{a}$ & 0.02 & 0.52 \\
\hline$V_{f 2}$ & $60.6 b$ & $103.2 \mathrm{a}$ & 91.1ab & $101.1 \mathrm{a}$ & 77.5ab & 4.7 & 0.005 \\
\hline$k_{2}$ & $0.03 \mathrm{ab}$ & $0.03 a b$ & $0.04 a$ & $0.03 a b$ & $0.03 b$ & 0.001 & 0.03 \\
\hline$\lambda$ & $8.1 \mathrm{a}$ & $3.4 b$ & $2.0 \mathrm{~b}$ & $2.8 \mathrm{~b}$ & $2.1 \mathrm{~b}$ & 0.5 & $<0.0001$ \\
\hline
\end{tabular}

Means followed by the same letter in columns do not differ $(\mathrm{P}>0.05)$ by Tukey test, $\mathrm{SEM}=$ standard error mean; $\mathrm{V}_{\mathrm{t} 1}=$ total volume observed $(\mathrm{mL} / \mathrm{g} \mathrm{DM}) ; \mathrm{V}_{\mathrm{t} 2}=$ total volume $(\mathrm{mL} / \mathrm{g} \mathrm{DM})$ estimated from the model; $\mathrm{V}_{\mathrm{f} 1}=$ volume $(\mathrm{mL})$ of gas produced by the degradation of the 
fraction $\mathrm{A}+\mathrm{B}_{1}$ of the Cornell System (NFC); $k_{1}=$ specific rate $\left(\mathrm{h}^{-1}\right)$ of gas production by the degradation of the fraction $A+B_{1}(N F C) ; V_{f 2}=$ volume $(m L)$ of gas produced by the degradation of the fraction $\mathrm{B}_{2}$ of fiber carbohydrates; $k_{2}=$ specific rate $\left(\mathrm{h}^{-1}\right)$ of production of gases by the degradation of the fraction $\mathrm{B}_{2}(\mathrm{FC}) ; \lambda=$ latency $(\mathrm{h})$.

\section{Discussion}

The species of the family Cactaceae present a high water storage capacity (Griffiths \& Males 2017). For this reason, they are known as being highly resistant to Semiarid regions. This particularity is confirmed by the high volume of water in the collected material (above $85 \%$ ) and, consequently, by the low dry matter (DM) content in the species evaluated. A high water content is fundamental for the survival of such species, and it makes them excellent sources of water to animals that extract water from food (Taddesse et al., 2014; Paiva et al., 2016). This fact emphasizes the importance of the inclusion of such forage plants in diets and contributes to meeting the requirements of this nutrient by animals, especially in the Semiarid region, where water is scarce.

The species $P$. gounelle $i$ had a low and $O$. inamoene had a high proportion of OM and EE. The OM present in such plants is related to the presence of other nutrients that can be digested, such as total carbohydrates, proteins and lipids. The EE is mainly the result of the waxes that protect the surface of such plants, part of an adaptation strategy of these forages to Semiarid regions. However, all species belonging to the family Cactaceae are poor in proteins, as they are part of a group of foods classified as energetic due to the presence of high amounts of carbohydrates (above $70 \%$ in most plants). This indicates that such cacti should not be offered to ruminants as a sole source of food. They should be offered to them in conjunction with other ingredients that can meet the nutrient requirements of the species and the categories of animals (Prieto-Garcia et al., 2016; Gouws et al., 2019).

Cavalcanti \& Resende (2007), evaluating the effects of the use of $C$. jamacaru and P. gounellei on the weight gain of goats during drought periods, concluded that the supply of diets composed exclusively of cacti did not meet the nutritional requirements of animals kept in confinement. However, when associated with protein and fiber ingredients, it was possible to meet such nutritional requirements. Silva et al., (2010) evaluated the use of $P$. gounellei and $C$. jamacaru associated with legume hay and the use of concentrates for lambs. There were no differences in DM intake among the animals that received $P$. gounellei or $C$. jamacaru, indicating that these two cactus can be used for animal feed without interfering in the intake of DM, provided they are associated to other sources of nutrients.

The high presence of NDF (above 40\%) in C. jamacaru does not that it will be less digestible since the presence of non-digestible fiber is low in plants of the Cactaceae family. In addition, the NDF of these species is composed mostly of HEM and CEL, which are susceptible to ruminal degradation although they are slow-digestion carbohydrates. The presence of less lignin in $C$. jamacaru plants can be explained by the initial treatment of the samples: we used only the external part of the plant for this species. Such part is offered to small ruminants in Caatinga regions. 
The greater presence of pectin in O. inamoene is related to the higher proportion of non-fibrous carbohydrates, since the pectin is contained in non-fibrous carbohydrates which is solubilized by the neutral detergent solution.

The species $C$. jamacaru, $M$. bahiensis and $O$. inamoene had the highest values of TDN. This can be explained by the high proportion of carbohydrates and the low ADL content, indicating that most compounds in these forages can be digestible. Just as the forages, $P$. gounelle $i$ and $P$. pachycladus presented low proportions of TDN and DE due to a high presence of ADL.

There is little information available in the literature on mineral content in native semiarid cacti and its effects on yield. Essential minerals play a vital role in the functioning of the animal organism. They participate in various metabolic processes and act in biochemical reactions and appear as activators or components of some specific enzymes. Among the native cactus studied, the genus Pilosocereus (Pilosocereus gounellei and Pilosocereus pachycladus) presented the highest levels of Calcium (56.1 and $58.5 \mathrm{~g} / \mathrm{kg}$ ), Magnesium (16.2 and $15.3 \mathrm{~g} / \mathrm{kg}$ ), Manganese (1880.6 and $1189.8 \mathrm{mg} / \mathrm{kg}$ ) and Zinc (49.0 and $45.0 \mathrm{mg} / \mathrm{kg}$ ) (Table 2). The higher concentrations observed are probably due to interactions between soil and plant nutrients. Correia et al., (2012) studying macronutrients and micronutrients contents of shoots (Pilosocereus gounellei subsp. Gounellei) shoots found values of $24.40 \mathrm{~g} / \mathrm{kg} \mathrm{Ca}, 58.47 \mathrm{~g} / \mathrm{kg}$ $\mathrm{Mg}, 178.40 \mathrm{mg} / \mathrm{kg} \mathrm{Mn}$ and, $156.70 \mathrm{mg} / \mathrm{kg} \mathrm{Zn}$.

The amount of calcium present in the evaluated native cactus species is within the limit recommended by the NRC (2001) for dairy cattle, whose range varies from 1: 1 to 7: 1, in a $\mathrm{Ca}: \mathrm{P}$ ratio. Calcium bioavailability in foods rich in phytic and oxalic acids has lower absorption, while carbohydrate and vitamin C rich foods have higher absorption (Hailu \& Addis 2015).

The total amount of nutrients in the plant increases with age, but the concentration in a given tissue may increase, decrease, or remain unchanged, depending on the nutrient and tissue. Seasonal changes in tissue nutrient concentrations occur, but they may result from changes in plant growth at a greater rate than changes in nutrient availability to the plant (Ai et al., 2017; du Toit et al., 2018). The plants need continuous supply of B for growth, this situation is justified by the high concentration of the element in the cell wall in structural form. Its deficiency directly impacts on cell structure, growth and division, and the death of meristematic tissue is one of the most common signs of B scarcity. Other factors indirectly affected by B deficiency are water absorption and root growth, as in the state deficiency occurs a reduction in the water absorption surface, and consequently, the nutrient reduction is also impaired (Wimmer \& Eichert, 2013; Chatterjee \& Bandyopadhyay 2017; Shireen et al., 2018).

Regarding the fractionation of nitrogen compounds, a higher content of fraction A was found, which corresponds to non-protein nitrogen in $C$. jamacaru. This means that this plant provides adequate supply of non-protein nitrogen compounds to the microbial population that ferment structural carbohydrates, and consequently also provides a protein fraction throughout the gastrointestinal tract. The B1 + B2 fraction is degraded at an intermediate rate in the rumen, which may be a source of amino acids and peptides for the same and small intestine. In foods where this fraction is significant, its evaluation is fundamental, since the amount effectively degraded in the rumen is a direct function of the passage rate, that is, it will depend on the 
degradation rate/passage rate ratio. However, it is extensively ruminally degraded, contributing to microbial nitrogen requirements in this compartment (Chrenková et al., 2014; Ferreira et al., 2018; Brandstetter et al., 2019). Although the amount of nitrogen in cacti is low, over $50 \%$ of the $\mathrm{N}$ present in the species evaluated are available for use by ruminal microorganisms, especially $C$. jamacaru and $M$. bahiensis, which presented an availability of $\mathrm{N}$ above $70 \%$, as they are components of the fractions A, B1+B2 and B3 (Table 3).

For fraction C, all species are above the limit of 5 to $10 \%$, which is considered for fodder the concentration of total lignin-bound nitrogen, making it unavailable (Van Soest 1994). Fraction $\mathrm{C}$ consists of lignin-associated proteins, tannic-protein complexes and Maillard reaction products, highly resistant to microbial and enzymatic degradation, and is therefore considered unusable in both the rumen and intestine (Chrenková et al., 2014) (Table 3).

Carbohydrates are the main source of energy for the ruminal microbiota, which in turn converts them into short-chain fatty acids (Loor et al., 2016). The highest proportion of the fraction B2 (potentially digestible fiber) and the lowest fraction $\mathrm{C}$ of carbohydrates of the species $C$. jamacaru is explained by the lowest presence of ADL in the material analyzed.

The fractions $\mathrm{A}+\mathrm{B} 1$ and $\mathrm{B} 2$ are composed of carbohydrates that can be degraded by ruminal microorganisms. More than $80 \%$ of the total carbohydrates of the cacti native from the Brazilian semiarid region can be digestible. These data confirm the forage potential of such species and the availability of carbohydrates, which are the main source of energy for ruminants in this region especially during periods of severe drought. According to Lima-Nascimento et al., (2019), in the northeast region of Brazil, which is mostly characterized by vegetation typical of the Caatinga, cacti are a symbol of resistance to limiting climatic conditions, with a rich diversity and abundance of species, represented by about 90 native species. Native cacti can be seen as a food strategy for periods of food shortage (Pérez-Marin et al., 2017).

Variation in carbohydrate fraction $\mathrm{C}$ content was not considered high, and according to Neumann et al., (2017) and Brandstetter et al., (2019) are significant differences in this fraction among forage species, since this fraction interferes with ruminal repletion, causing a lower energy availability due to its indigestible characteristic, as it results in lower food consumption in unit time. Plants with high levels of this fraction interfere with the animal food intake, so this forage should be supplemented with energy sources of rapid rumen availability (Mendoza et al., 2014), when it does not have protein limitation in quantity and quality.

Potential degradation was above $60 \%$ for all species. The cactus $C$. jamacaru and M. bahiensis presented a high PD. The difference between these two species in relation to the others is due to the great availability of carbohydrates to ruminal micro-organisms present in these cactus, since 96.1 and $94.4 \%$, respectively for each species above, of these carbohydrates can be digested, although all species have a high percentage of carbohydrates, which may result in different degradation rates. Another factor that may have interfered with degradation is the proportion of the fraction $\mathrm{C}$ of carbohydrates and the amount of lignin in some species (Tables 1 and 4). 


\section{Ml Macrothink}

Journal of Agricultural Studies

ISSN 2166-0379

2019, Vol. 7, No. 4

There were differences in the parameters $a$ and $b$ and the effective degradability in function of $a$ slow and average passage rate. However, when an ED for a fast passage rate was estimated, it was observed that there were no differences among species. In addition to the fact that there were no differences in fast passage rates between the species, it was observed that degradation decreased. This happens due to the short time of exposure to which this food is subjected in the ruminal environment.

The lowest Vt1 produced by TC fermentation of P. pachycladus $(192.4 \mathrm{~mL} / \mathrm{g} \mathrm{DM})$ was due to the low proportion of total carbohydrates present in its composition, and also due to a low Pd. As for the adjustment of the two-compartment model, there was less precision in the adjustment only for $C$. jamacaru plants probably due to the fermentation characteristics of the carbohydrates present in the composition of this species.

There was a high gas production by $P$. gounellei and $M$. bahiensis. The difference in gas production from fiber and non-fiber carbohydrates is related to the chemical composition of these species and the rate of degradation of the compounds present in each species. In general, for cactaceae that are rich in non-fiber carbohydrates, there is a tendency of a higher gas production from such carbohydrates, confirming their greater degradation.

The species $C$. jamacaru presented the highest gas production, but it depended on a longer time to establish the fermentation completely, reflecting in a longer lag time, or latency phase. In addition, a fermentation different from that of $C$. jamacaru, in relation to the other species, was probably due to its chemical composition, which may hinder the adhesion of the microorganisms to the substrate. Although the highest final volume was obtained by $\mathrm{C}$. jamacaru, the degradation curve indicated high yields up to 42 hours and a better adjustment for O. inamoene.

\section{Conclusion}

The evaluated cacti have a satisfactory chemical composition capable of supplying part of the daily energy needs of animals in Caatinga areas as it presents high levels of potentially digestible fractions of total carbohydrates. This confirms the importance of their use for feeding ruminants, especially during periods of severe drought. During such periods, Caatinga's cacti are a basal forage resource.

\section{Conflict of interest}

The authors declare that they have no competing interests.

\section{References}

Afrc. (1993). Agricultural and Food Reaserch Council. Energy and protein requirements of ruminants. Wallingford: CAB International, 159p.

Ai, Z., Wang, G., Liang, C., Liu, H., Zhang, J., Xue, S., \& Liu, G. (2017). The effects of nitrogen addition on the uptake and allocation of macroand micronutrients in bothriochloa ischaemum on loess plateau in China. Frontiers in Plant Science, 8, 1-12. https://doi.org/10.3389/fpls.2017.01476 
Alves, F. A. L., Andrade, A. P., Bruno, R. L. A, Santos, D. C., Magalhaes, A. L. R., \& Silva, D. S. (2017). Chemical and nutritional variability of cactus pear cladodes, genera Opuntia and Nopalea. American Journal of Food Technology, 12, 25-34.

https://doi.org/10.3923/ajft.2017.25.34

Aoac. (2016). Association of Official Analytical Chemists. Official methods of analysis of AOAC International. Ed., Latimer Jr., G.W. 20th ed. Washington (D.C.). p. 3100.

Boufennara, S., Bouazza, L., Veja, A., Fondevila, M., Amanzougarene, Z., \& Lopez, S. (2016). In vitro assessment of nutritive value of date palm by-products as feed for ruminants. Emirates Journal of Food and Agriculture, 28, 695-703.

https://doi.org/10.9755/ejfa.2016-01-104

Brandstetter, E. V., Costa, K. A. P., Santos, D. C., Souza, W. F., Silva, V. C., \& Dias, M. B. C. (2019). Protein and carbohydrate fractionation of Jiggs Bermudagrass in different seasons and under intermittent grazing by Holstein cows. Acta Scientiarum. Animal Sciences, 41, e43363. https://dx.doi.org/10.4025/actascianimsci.v41i1.43363

Canteri-Schemin, M. H., Fertonani, H. C. R., Waszczynskyj, N., \& Wosiacki, G. (2005). Extraction of pectin from apple pomace. Brazilian Archives of Biology and Technology, 48, 259-266. https://doi.org/10.1590/S1516-89132005000200013

Carvalho, C. B. M., Edvan, R. L., Carvalho, M. L. A. M., Reis, A. L. A., \& Nascimento, R. R. (2018). Use of cacti in animal feed and post-harvest storage. Archivos de Zootecnia, 67, 440-446. https://dx.doi.org/10.21071/az.v67i259.3803

Cavalcanti, N. B., \& Resende, G. M. (2007). Consumo de xiquexique (Pilocereus gounellei (A. Weber ex K. Schum.) Bly. ex Rowl) por caprinos no Semi-árido da Bahia. Revista Caatinga, 20, 22-27. https://periodicos.ufersa.edu.br/index.php/caatinga/article/view/107/pdf

Chatterjee, R., \& Bandyopadhyay, S. (2017). Effect of boron, molybdenum and biofertilizers on growth and yield of cowpea (Vigna unguiculata L. Walp.) in acid soil of eastern Himalayan region. Journal of the Saudi Society of Agricultural Sciences, 16, 332-336. https://doi.org/10.1016/j.jssas.2015.11.001

Chaves, L. C. G., Lopes, F. B., Maia, A. R. S., Meireles, A. C. M., \& Andrade, E. M. (2019). Water quality and anthropogenic impact in the watersheds of service reservoirs in the Brazilian semi-arid region. Revista Ciência Agronômica, 50,

223-233. https://dx.doi.org/10.5935/1806-6690.20190026

Chrenková, M., Čerešňáková, Z., Weisbjerg, M. R., Formelová, Z., Poláčiková, M., \& Vondráková, M. (2014). Characterization of proteins in feeds according to the CNCPS and comparison to in situ parameters. Czech Journal of Animal Science, 59, 288-295. https://doi.org/10.17221/7499-CJAS

Correia, D., Nascimento, E. H. S., Araújo, J. D. M., \& Oliveira, A. E. R. (2012). Produção de mudas de xique-xique. Embrapa Agroindústria Tropical. 1. Ed., Fortaleza, CE. Circular Técnica, 40. 
du Toit, A., e Wit, M., \& Hugo, A. (2018). Cultivar and harvest month influence the nutrient content of Opuntia spp. cactus pear cladode mucilage extracts. Molecules, 23, 1-12. https://dx.doi.org/10.3390/molecules23040916

Ferreira, D. J., Zanine, A. M., Lana, R. P., Souza, A. L., Negrão, F. M., Geron, L. J. V., ... Parente, M. O. M. (2018). Carbohydrate and protein fractioning of grass silages with added dehydrated brewery residue. Ciencia e Investigacion Agraria, 45, 192-199.

https://dx.doi.org/10.7764/rcia.v45i2.1807

Furtado, R. N., Carneiro, M. S. S., Pereira, E. S., Moreira Filho, E. C., Magalhães, J. A., \& Oliveira, S. M. P. (2016). Intake, milk yield, and physiological parameters of lactating cows fed on diets containing different quantities of xiquexique (Pilosocereus gounellei). Semina: Ciências Agrárias, 37, 483-494. http://dx.doi.org/10.5433/1679-0359.2016v37n1p483

Gouws, C. A., Georgousopoulou, E. N., Mellor, D. D., McKune, A., \& Naumovski, N. (2019). Effects of the consumption of prickly pear cacti (Opuntia spp.) and its products on blood glucose levels and insulin: A Systematic review. Medicina, 55, 1-18.

https://dx.doi.org/10.3390/medicina55050138

Griffiths, H., \& Males, J. (2017). Succulent plants. Current Biology, 27, 890-896. https://doi.org/10.1016/j.cub.2017.03.021

Hailu, A. A., \& Addis, G. (2016). The content and bioavailability of mineral nutrients of selected wild and traditional edible plants as affected by household preparation methods practiced by local community in Benishangul Gumuz regional state, Ethiopia. International Journal of Food Science, 2016, 1-7. https://doi.org/10.1155/2016/7615853

Holden, L. A. (1999). Comparison of methods of in vitro dry matter digestibility for ten feeds. Journal of Dairy Science, 82, 1791-1794. https://doi.org/10.3168/jds.S0022-0302(99)75409-3

Kalegowda, P., Haware, D. J., Rajarathnam, S., \& Shashirekha, M. N. (2015). Minerals of cactus (Opuntia dillenii): cladode and fruit. Current Science, 109, 2295-2298. https://doi.org/10.18520/cs/v109/i12/2295-2298

Licitra, G., Hernandez, T. M., \& Van Soest, P. J. (1996). Standardization of procedures for nitrogen fracionation of ruminant feed. Animal Feed Science and Technology, 57, 347-358. https://doi.org/10.1016/0377-8401(95)00837-3.

Lima-Nascimento, A. M., Bento-Silva, J. S., Lucena, C. M., \& Lucena, R. F. P. (2019). Ethnobotany of native cacti in the northeast region of Brazil: Can traditional use influence availability? Acta Botanica Brasilica, 33, 350-359.

https://doi.org/10.1590/0102-33062019abb0166

Loor, J. J., Elolimy, A. A., \& McCann, J. C. (2016). Dietary impacts on rumen microbiota in beef and dairy production. Animal Frontiers, 6, 22-29. https://doi.org/10.2527/af.2016-0030

Lucena, C. M., Lucena, R. F. P., Costa, G. M., Carvalho, T. K. N., Costa, G. G. S., Alves, R. R. N., ... Nunes, E. N. (2013). Use and knowledge of Cactaceae in Northeastern Brazil. Journal of Ethnobiology and Ethnomedicine, 9, 1-11. https://doi.org/10.1186/1746-4269-9-62 
Marten, G. C., \& Barnes, R. F. (1979). Prediction of energy digestibility of forages with in vitro rumen fermentation and fungal enzymes systems. In W. J. Pigden, C. C. Balch, \& M. Graham, (Eds.), Standardization of analytical methodology for feeds. (pp. 61-128). Ottawa: International Development Research. Center.

Mendoza, G. D., Loera-Corral, O., Plata-Pérez, F. X., Hernández-García, P. A., \& Ramírez-Mella, M. (2014). Considerations on the use of exogenous fibrolytic enzymes to improve forage utilization. The Scientific World Journal, 2014, 1-9.

https://doi.org/10.1155/2014/247437

Mertens, D. R. (2002). Gravimetric determination of amylase-treated neutral detergent fiber in feeds with refluxing in beaker or crucibles: Collaborative study. Journal of AOAC International, 85, 1217-1240. https://www.ncbi.nlm.nih.gov/pubmed/12477183

Monteiro, E. R., Strioto, D. K., Meirelles, A. C. S., Mangolin, C. A., \& Machado, M. F. P. S. (2015). Genetic structure of Pilosocereus gounellei (Cactaceae) as revealed by AFLP marker to guide proposals for improvement and restoration of degraded areas in Caatinga biome. Genetics and Molecular Research, 14, 16966-16974.

https://doi.org/10.4238/2015.December.15.2

Neumann, M., Nörnberg, J. L., Leão, G. F. M., Horst, E. H., \& Figueira, D. N. (2017). Chemical fractionation of carbohydrate and protein composition of corn silages fertilized with increasing doses of nitrogen. Ciência Rural, 47, e20160270.

https://doi.org/10.1590/0103-8478cr20160270

Nogueira, A. R. A., \& Souza, G. B. (2005). Tecido vegetal. Manual de laboratórios: solo, água, nutrição vegetal, nutrição animal e alimentos. São Carlos: Embrapa Pecuária Sudeste; 334 p.

Nrc. (2001). National Research Council. Nutrient Requirements of Dairy Cattle. 7ed. Washington DC: National Academy Press, 381p.

Ørskov, E. R., \& McDonald, I. (1979). The estimation of protein degradability in the rumen from incubation measurements weighted according to rate of passage. Journal of Agricultural Science, 92, 499-503. https://doi.org/10.1017/S0021859600063048.

Paiva, P. M. G., Souza, I. F. A. C., Costa, M. C. V. V., Santos, A. F. S., \& Coelho, L. C. B. B. (2016). Opuntia sp. cactus: Biological characteristics, cultivation and applications. Advances in Research, 7, 1-14, https://doi.org/10.9734/AIR/2016/26125

Pérez-Marin, A. M., Rogé, P., Altieri, M. A., Forero, L. F. U., Silveira, L., Oliveira, V. M., \& Domingues-Leiva, B. E. (2017). Agroecological and social transformations for coexistence with Semi-Aridity in Brazil. Sustainability, 9, 1-17. https://dx.doi.org/10.3390/su9060990

Pinheiro, E. A. R., van Lier, Q. J., \& Bezerra, A. H. F. (2017). Hydrology of a water-limited forest under climate change scenarios: The case of the Caatinga biome, Brazil. Forests 2017, 8, 62. https://dx.doi.org/10.3390/f8030062 1-15

Prieto-García, F., Prieto Méndez, J., Sandoval, O. A. A., Canales Flores, R. A., \& Santillán, Y. M. (2016). Chemical and physical characterization of Opuntia spp. seeds grown in Hidalgo 
State, Mexico. Ciencia e investigación agraria, 43, 143-150.

https://dx.doi.org/10.4067/S0718-16202016000100013

Santos, C. B., Costa, K. A. P., Souza, W. F., Costa e Silva, V., Epifanio, P. S., \& Santos, H. S. (2019). Protein and carbohydrates fractionation in Paiaguas palisade grass intercropped with grain sorghum in pasture recovery. Acta Scientiarum. Animal Sciences, 41, 1-8. https://doi.org/10.4025/actascianimsci.v41i1.42693

Sas. (2011). Statistical analysis system institute. SAS/STAT User's guide version 9.2. Cary: SAS Institute; $8621 \mathrm{p}$.

Schofield, P., Pitt, R. E., \& Pell, A. N. (1994). Kinetics of fiber digestion from in vitro gas production. Journal of Animal Science, 72, 2980-2991. https://doi.org/10.2527/1994.72112980x

Shireen, F., Nawaz, M. A., Chen, C., Zhang, Q., Zheng, Z., Sohail, H., ... Bie, Z. (2018) Boron: Functions and approaches to enhance its availability in plants for sustainable agriculture. International Journal of Molecules Science, 19, 1-20. https://doi.org/10.3390/ijms 19071856

Silva, D. J., Queiroz, A. C. (2002). Análise de alimentos: métodos químicos e biológicos. 2. ed. Viçosa, MG: UFV/Imprensa Universitária, 235p.

Silva, J. G. M., Lima, G. F. C., Aguiar, E. M., Melo, A. A. S., \& Rêgo, M. M. T. (2010). Native cacti associated with sabiá and flor de seda shrub hays in male lamb feeding. Revista Caatinga, 23, 123-129.

https://periodicos.ufersa.edu.br/index.php/caatinga/article/view/1762/4601

Sniffen, C. J., O’Connor, J. D., \& Van Soest, P. J. (1992). A net carbohydrate and protein system for evaluating cattle diets: II. Carbohydrate and protein availability. Journal Animal Science, 70, 3562-3577. https://www.ncbi.nlm.nih.gov/pubmed/1459919

Taddesse, D., Melaku, S., \& Mekasha, Y. (2014). Assessment of herd structure and use of cactus (Opuntia ficus indica) and indigenous browse species as livestock feed in Miesso, Eastern Ethiopia. American Scientific Research Journal for Engineering, Technology, and Sciences, 10, 10-27.

https://pdfs.semanticscholar.org/db48/6a45b306740f495a62d8580bc77af035687a.pdf

Theodorou, M. K., Williams, B. A., Dhanoa, M. S., McAllan, A. B., \& France, J. (1994). A simple gas production method using a pressure transducer to determine the fermentation kinetics of ruminant feeds. Animal Feed Science and Technology, 48, 185-197. https://doi.org/10.1016/0377-8401(94)90171-6

Tilley, J. M. A., \& Terry, R. A. (1963). A two-stage technique for the in vitro digestion of forage crops. Grass and Forage Science, 18, 104-111. https://onlinelibrary.wiley.com/doi/abs/10.1111/j.1365-2494.1963.tb00335.x

Valente, T. N. P., Detmann, E., Queiroz, A. C., Valadares Filho, S. C., Gomes, D. I., \& Figueiras, J. F. (2011). Evaluation of ruminal degradation profiles of forages using bags made from different textiles. Revista Brasileira de Zootecnia, 40, 
2565-2573. https://dx.doi.org/10.1590/S1516-35982011001100039

Van Soest, P. J. (1994). Nutritional ecology of the ruminant. (2.ed). Cornell University Press: Ithaca, $476 \mathrm{p}$.

Van Soest, P. J., Robertson, J. B., \& Lewis, B. A. (1991). Methods for dietary fiber, neutral detergent fiber, and nonstarch polyssacharides in relation to animal nutrition. Journal Dairy Science, 74, 3583-3597. https://doi.org/10.3168/jds.S0022-0302(91)78551-2

Wimmer, M. A., \& Eichert, T. (2013). Review: Mechanisms for boron deficiency-mediated changes in plant water relations. Plant Science, 203-204, 25-32.

https://doi.org/10.1016/j.plantsci.2012.12.012

Zanella, K., \& Taranto, O. P. (2015). Influence of the drying operating conditions on the chemical characteristics of the citric acid extracted pectins from "pera" sweet orange (Citrus sinensis L. Osbeck) albedo and flavedo. Journal of Food Engineering, 166, 111-118. https://doi.org/10.1016/j.jfoodeng.2015.05.033

\section{Copyright Disclaimer}

Copyright for this article is retained by the author(s), with first publication rights granted to the journal.

This is an open-access article distributed under the terms and conditions of the Creative Commons Attribution license (http://creativecommons.org/licenses/by/4.0/). 